\title{
Bilateral Torsion of Intra-abdominal Seminoma Presenting with Acute Abdomen and Intra-peritoneal Bleeding: A Case Report
}

\author{
Akut Karın ve Intraperitoneal Kanamaya Bağlı Intraabdominal Seminomun Iki Taraflı \\ Torsiyonu: Bir Olgu Sunumu
}

\author{
(D) Omar Fahmy1, (D) Abdal-Rahman Shaker², (D) Syed H.S.M. Hadi1, (D) Christopher K.S. Lee1, (D) RAH Erman11, (D) Mohd Khairul-Asri1 \\ 1 University of Putra Malaysia Faculty of Medicine, Department of Urology, Selangor, Malaysia \\ 2 University of Putra Malaysia Faculty of Medicine, Department of General Surgery, Selangor, Malaysia
}

\begin{abstract}
Seminoma is the most frequently reported tumor in patients with intra-abdominal testicles. In very rare cases, it might present with torsion or rupture. We report a 41-year-old man who presented with acute abdominal pain due to torsion of large bilateral intra-abdominal testicular tumors with rupture of the right-sided mass. Bilateral orchiectomy was performed and histopathological examination revealed bilateral seminoma. Postoperative staging imaging displayed no lymphadenopathy or metastatic lesions. No adjuvant treatment was required and the patient is clinically well and under regular follow-up. This case represents an extremely rare presentation of bilateral testicular cancer with a pleasant outcome.
\end{abstract}

Keywords: Bilateral cryptorchidism, Bilateral seminoma, Intra-abdominal testicle, Ruptured seminoma, Testicular torsion

Öz

Kriptorşidizm, testis tümörleri gelişme olasılığı yüksek, erkek cinsiyette görülen yaygın doğumsal anomalidir. Seminom, intraabdominal testisli hastalarda bildirilen en sık görülen tümördür. Genellikle abdominal kitlesi veya metastatik hastalığı bulunur, ancak nadir durumlarda torsiyon veya kopma olabilir. Akut karın ağrısı ve intraperitoneal kanama ile başvuran 41 yaşındaki erkek hasta üzerinde rapor veriyoruz. Resüsitasyondan sonra, cerrahi eksplorasyon, sağ taraflı kitle rüptürü ile geniş bilateral intraabdominal testis tümörlerinin torsiyonunu gösterdi. Bilateral orşiektomi yapıldı ve histopatolojik incelemede bilateral seminom tespit edildi. Postoperatif evreleme görüntülemesinde, tümör belirteçlerinin normalleştirilmesi ile birlikte lenfadenopati veya metastatik lezyon görülmedi. Hiçbir adjuvan tedavi gerekmemekteydi ve hasta klinik olarak iyi takip edildi ve düzenli takibe alındı. Bu olgu, bilateral testis kanserinin nadir görülen ve iyi sonuç veren bir sunumudur.

Anahtar Kelimeler: Bilateral kriptorşidizm, Bilateral seminom, İntraabdominal testis, Rüptüre seminom, Testis torsiyonu

\section{Introduction}

Cryptorchidism is the commonest congenital anomaly in male gender with overall incidence rate of 1-2\% (1). Up to $23 \%$ of cases can present with bilateral disease, and the testicles can be located along the course of normal descent or in an ectopic position, including the abdominal cavity (2). The risk of malignant transformation is very high if orchiopexy was not performed before puberty (3). Seminoma is the commonest testicular tumor detected in uncorrected cryptorchidism (4). In this paper, we present an extremely rare case of bilateral intra- abdominal tumors which presented with acute abdomen and intra-peritoneal bleeding due to bilateral torsion and rupture of one of the tumors.

\section{Case Presentation}

A 41-year-old male patient presented to the emergency department with the complaint of severe abdominal pain for 48 hours. The pain started in the right iliac fossa then became generalized. On physical examination, the vital signs were

Correspondence: Omar Fahmy MD, University of Putra Malaysia Faculty of Medicine, Department of Urology, Selangor, Malaysia Phone:+603 89472667 E-mail: omarfahmy.ahmed@upm.edu.my ORCID-ID: orcid.org/0000-0002-7017-2516

Received: 19.09.2017 Accepted: 15.11.2017

Cite this article as: Fahmy 0, Shaker AR, Hadi SHSM, Lee CKS, Erman R, Asri MK. Bilateral Torsion of Intra-abdominal Seminoma Presenting with Acute Abdomen and Intra-peritoneal Bleeding: A Case Report. J Urol Surg 2018;5(4):199-201.

${ }^{\circledR}$ Copyright 2018 by the Association of Urological Surgery / Journal of Urological Surgery published by Galenos Publishing House. 
unstable; heart rate, respiration, blood pressure were 126/ $\mathrm{min}, 21 / \mathrm{min}$, and $98 / 63 \mathrm{mmHg}$, respectively. Severe abdominal tenderness and guarding were detected mainly in the right iliac fossa. Genital examination showed absent bilateral testicles. Sonographic imaging revealed free fluid in the peritoneal cavity and a heterogeneous soft tissue lesion in the lower part of the abdomen. He was resuscitated with intravenous fluids, and analgesia was given. As the patient was unstable, after proper counseling, laparoscopic laparotomy was performed and then, was converted to lower midline laparotomy that revealed bilaterally twisted intra-abdominal gonadal tumors (Figure 1). No obvious metastasis was detected after careful inspection of the abdominal cavity and lymph nodes. Removal of the two tumors, followed by closure of the abdomen was performed.

Postoperatively, alpha fetoprotein (AFP) and beta-human chorionic gonadotropin ( $\beta-\mathrm{HCG}$ ) levels were not raised, however, lactate dehydrogenase (LDH) was high (1160 U/L). Seven days later, LDH was normalized. Contrast-enhabced computed tomography (CT) showed non-metastatic disease. Pathological reporting displayed seminoma, which infiltrated the tunica albuginea, without extension to any other structures. Until now, after 6 months of postoperative follow up, the patient still well with no detected tumor recurrence.

Written informed consent was taken for publication of the case report.

\section{Discussion}

The incidence of undescended testicles at the time of birth is up to $30 \%$ and $8 \%$ in premature and full-term boys, respectively (2). Due to the increased testosterone level around the age of 3 months, possibility of spontaneous descent is quit high (2). After

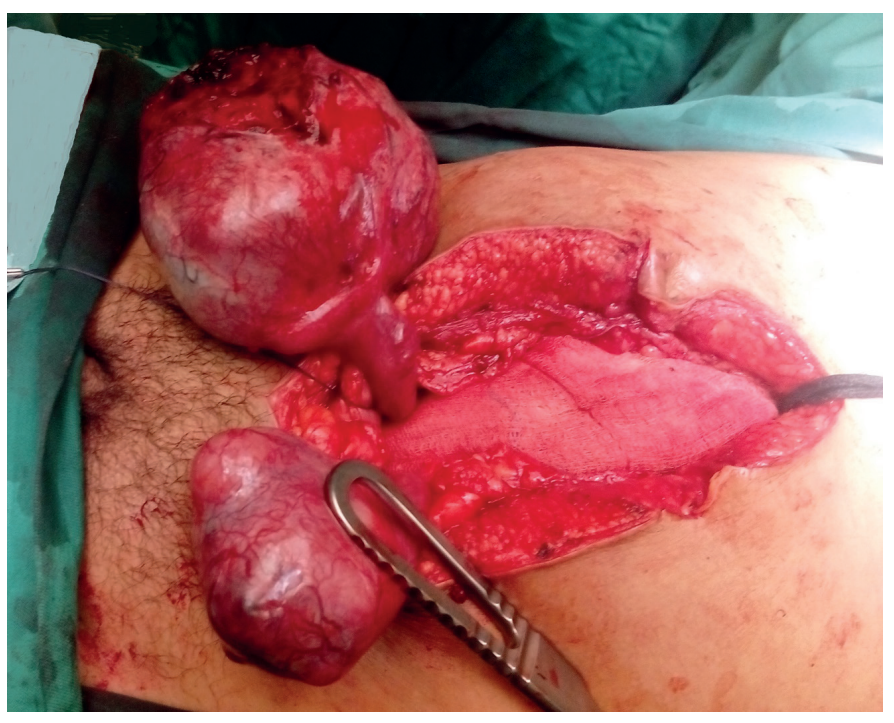

Figure 1. Bilateral testicular masses with rupture of the right sided tumor
6 month of age, spontaneous descent is unlikely to be observed, therefore, orchiopexy is the standard treatment (5). The overall incidence at 1 year of age is 1-2\% (1). Orchiopexy should be performed before 12 months of age to avoid the damage to germ cells (6).

It is well established that cryptorchidism increases the risk of testicular cancer. The possibility of cancer development is about 40 times higher than in people born with scrotal testicles (1). The pathogenesis of cancer development is still not completely understood, however, one of the theories is the destructive effect of increased temperature on the germ cells, which can be a source of carcinoma in situ after puberty (1). Orchiopexy after puberty does not decrease the risk of malignant transformation (7), yet it increases the possibility for earlier detection of the cancer. In adult patients with intra-abdominal undescended testicles, unfortunately the diagnosis of cancer at early stage is difficult and usually patients present with advanced disease or palpable mass.

Seminoma is the most frequently diagnosed tumor in undescended testicles, especially in patients who had not undergone orchiopexy (1). LDH, AFP, and $\beta$-HCG are the most commonly used tumor markers for testicular germ cell tumors. In seminoma, elevated LDH reflects a large tumor size and high tissue destruction level, yet its specificity is low (8). AFP and $\beta$-HCG levels are not usually elevated in seminoma. Only with mixed content, such as embryonic carcinoma or syncytiotrophoblast, AFP and $\beta$-HCG can be elevated, respectively. Elevated tumor markers might be associated with a poor prognosis, however, the curability of seminoma is high in general (8).

Torsion with subsequent severe pain due to ischemia is more common in undescended testicle than in the scrotal one (9). Bulky testicular tumors are vulnerable to rupture after complete twist of the spermatic cord with subsequent significant bleeding and hemorrhagic shock. Despite torsion might be life-threatening due to bleeding, it can be the leading cause to detect the tumor in an early stage before metastasis.

Clinical staging using contrast-enhanced CT and tumor markers is mandatory before surgical intervention in testicular tumors (10). In our case, the patient underwent urgent surgical intervention in view of the clinical instability. Contract-enhanced CT scan and analysis of tumor markers were performed postoperatively for staging and planning for any required adjuvant therapy. Fortunately, no metastatic lesion or persistently elevated markers was detected, thus, no adjuvant treatment was considered.

The take-home message is that cryptorchidism is best to detect immediately after birth to avoid further complications. The recommendation for orchiopexy of undescended testis in early childhood -ideally before 12 months of life- must be followed strictly. Prepubertal detected cryptorchidism should be corrected 
with orchiopexy. Adult patients with cryptorchidism should be counseled for orchiectomy or orchiopexy which with allow regular self-examination without reduction of carcinogenesis (7). However, extremely rare, this case report highlights intraabdominal seminoma as a cause for acute abdomen that should be considered in patients with a history of undescended testicles or accidently discovered during clinical examination. Scrotal examination should be included in clinical assessment of patients presenting with acute abdomen.

\section{Ethics}

Informed Consent: It was taken for publication of the case report.

Peer-review: Externally peer-reviewed.

\section{Authorship Contributions}

Surgical and Medical Practices: O.F., Concept: M.K.A., Design: A.R.S., Data Collection or Processing: S.H.S.M.H., Analysis or Interpretation: C.K.S.L., Literature Search: R.E., Writing: O.F.

Conflict of Interest: No conflict of interest was declared by the authors.

Financial Disclosure: The authors declared that this study received no financial support.

\section{References}

1. Wood HM, Elder JS. Cryptorchidism and testicular cancer: separating fact from fiction. J Urol 2009;181:452-461.

2. Niedzielski JK, Oszukowska E, Słowikowska-Hilczer J. Undescended testis - current trends and guidelines: a review of the literature. Arch Med Sci 2016;12:667-677.

3. Schneck FX, Bellinger MF. Abnormalities of the testis and scrotum: surgical management. In: Wein AJ, Kavoussi LR, Novick AC, Partin AW, Peters CA. Campbell-Walsh Urology, 9th ed. Philadelphia, WB Saunders Co 2006; pp 127.

4. Martin DC. Germinal cell tumors of the testis after orchiopexy. J Urol 1979;121:422-424.

5. Hutson JM, Li R, Southwell BR, Petersen BL, Thorup J, Cortes D. Germ cell development in the postnatal testis: the key to prevent malignancy in cryptorchidism? Front Endocrinol (Lausanne) 2013;3:176.

6. Ritzén EM. Undescended testes: a consensus on management. Eur J Endocrinol 2008;159(Suppl 1):87-90.

7. Pettersson A, Richiardi L, Nordenskjold A, Kaijser M, Akre O. Age at surgery for undescended testis and risk of testicular cancer. N Engl J Med 2007;356:1835-1841.

8. Dong W, Gang W, Liu M, Zhang H. Analysis of the prognosis of patients with testicular seminoma. Oncol Lett 2016;11:1361-1366.

9. Mathers MJ, Sperling $H$, Rübben $H$, Roth $S$. The Undescended Testis: Diagnosis, Treatment and Long-Term Consequences. Dtsch Ärztebl Int 2009;106:527-532.

10. Albers $P$, Albrecht $W$, Algaba $F$, Bokemeyer $C$, Cohn-Cedermark $G$, Fizazi K, Horwich A, Laguna MP, Nicolai N, Oldenburg J; European Association of Urology. Guidelines on Testicular Cancer: 2015 Update. Eur Urol 2015;68:1054-1068 